\title{
Prehistoric Sites in the Sabine River Valley in Northeastern Smith County, Texas Timothy K. Perttula and Mark Walters
}

Timothy K. Perttula

Heritage Research Center, Stephen F. Austin State University

Mark Walters

Heritage Research Center, Stephen F. Austin State University

Follow this and additional works at: https://scholarworks.sfasu.edu/ita

Part of the American Material Culture Commons, Archaeological Anthropology Commons, Environmental Studies Commons, Other American Studies Commons, Other Arts and Humanities Commons, Other History of Art, Architecture, and Archaeology Commons, and the United States History Commons

Tell us how this article helped you.

This Article is brought to you for free and open access by the Center for Regional Heritage Research at SFA ScholarWorks. It has been accepted for inclusion in Index of Texas Archaeology: Open Access Gray Literature from the Lone Star State by an authorized editor of SFA ScholarWorks. For more information, please contact cdsscholarworks@sfasu.edu. 
Prehistoric Sites in the Sabine River Valley in Northeastern Smith County, Texas Timothy K. Perttula and Mark Walters

\section{Creative Commons License}

\section{(c) (1) \&}

This work is licensed under a Creative Commons Attribution-NonCommercial 4.0 International License 


\section{Prehistoric Sites in the Sabine River Valley in Northeastern Smith County, Texas}

\section{Timothy K. Perttula and Mark Walters}

\section{INTRODUCTION}

In the winter of 2003, the junior author completed archaeological survey investigations of a small area of the Sabine River valley in northeastern Smith County in the East Texas Pineywoods (Figure 1). The work consisted of limited surface collections and shovel tests, and four archaeological sites were found during the work. The sites are about 2.4-3.0 km south-southwest of the Early Caddo period Boxed Spring mound site (41UR30) on the north side of the Sabine River (Perttula 2011).

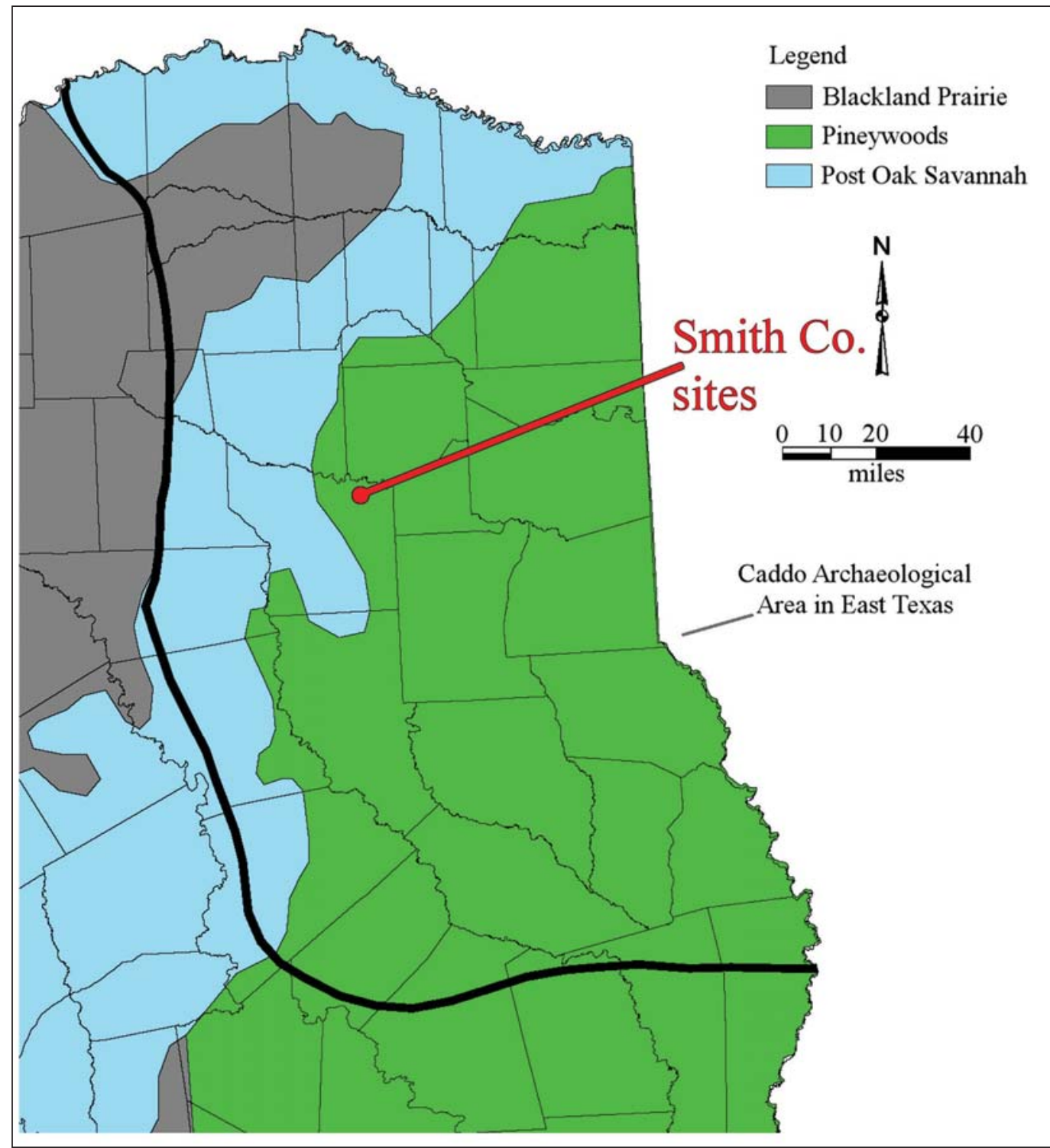

Figure 1. Location of Smith County sites in East Texas. 
Two of the archaeological sites (41SM307 and 41SM308) are situated on alluvial landforms in the Sabine River valley at elevations of ca. 280-290 ft. amsl (Figure 2). The other two (41SM309 and 41SM310) are on upland landforms at elevations of $310 \mathrm{ft}$. amsl and $350 \mathrm{ft}$. amsl, respectively.

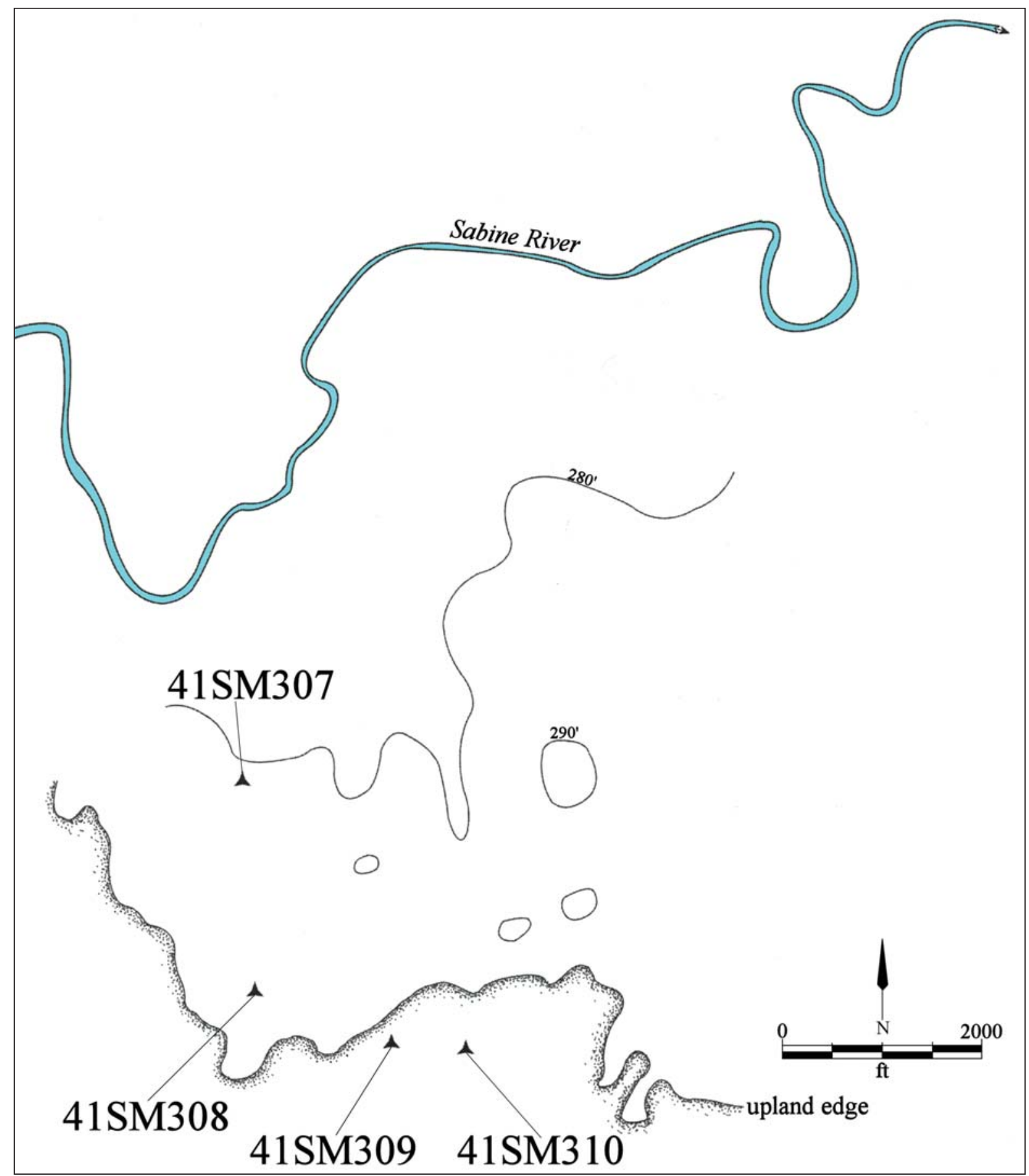

Figure 2. Location of the sites in the Sabine River valley. 


\section{Cabin Site (41SM307)}

The Cabin site covers less than $1000 \mathrm{~m}^{2}$ of an alluvial landform overlooking the Sabine River floodplain (see Figure 2). Two shovel tests (ST 1 and ST 3 ) have artifacts (2.5 artifacts/positive shovel test) between $20-60 \mathrm{~cm}$ bs in loam and sandy loam deposits. The artifacts are comprised of a cortical gray chert piece of lithic debris in ST 3 (20-40 cm bs) and four plain body sherds from grog-tempered vessels in ST 1 (20-58 $\mathrm{cm} \mathrm{bs}$ ) and ST $3(40-60 \mathrm{~cm} \mathrm{bs})$. One of the plain grog-tempered sherds is from a vessel with a distinctive sandy paste. The likely age of this site is not known at present.

\section{Larry Byrd Pine Plantation Site (41SM308)}

This site was investigated with the excavation of nine shovel tests (ST 1-9) and a small surface collection. The seven positive shovel tests suggest that the Larry Byrd Pine Plantation site covers a ca. 50 x $60 \mathrm{~m}$ area of an alluvial landform (see Figure 2). The archaeological deposits at the site extend from $20-80 \mathrm{~cm}$ bs in sandy loam deposits that range from brown to dark yellowish-brown to very dark brown in color.

Artifacts recovered in the seven positive shovel tests (ST 2-5, 7-9) include burned clay pieces, plain ceramic sherds, lithic debris, and wood charcoal (Table 1). The mean density of artifacts is 7.6 per positive shovel, or ca. 60 artifacts per $\mathrm{m}^{2}$. The highest artifact densities are between $40-80 \mathrm{~cm} \mathrm{bs}$, particularly the densities of plain ceramic sherds. ST 7, near the edge of the alluvial landform, has the highest artifact density $(\mathrm{n}=21,40-80 \mathrm{~cm}$ bs) of any of the shovel tests.

Table 1. Distribution of artifacts in the shovel testing at the Larry Byrd Plantation Site (41SM308).

\begin{tabular}{llllll}
\hline $\begin{array}{l}\text { Depth } \\
(\mathrm{cm} \mathrm{bs})\end{array}$ & Burned Clay & Plain Sherds & Lithic Debris & Wood Charcoal & $\mathrm{N}$ \\
\hline $0-20$ & - & 2 & 1 & - & 3 \\
$20-40$ & 5 & 1 & 2 & - & 8 \\
$40-60$ & 8 & 7 & 3 & - & 18 \\
$60-80$ & 4 & 17 & 1 & 2 & 24 \\
\hline Totals & 17 & 27 & 7 & 2 & 53 \\
\hline
\end{tabular}

The burned clay pieces from two shovel tests (ST 5 and ST 7) may represent the remnants of cooking features preserved in the archaeological deposits, or evidence of other heating activities, as does the wood charcoal from ST $2(60-80 \mathrm{~cm}$ bs). The few pieces of lithic debris suggest that raw materials were knapped on the site, either to reduce river gravels or thin and shape pebbles into tools. The lithic debris includes a reddish-brown chert $(n=1,100$ percent cortical), dark gray chert $(n=2,50$ percent cortical), yellow chert $(n=2)$, grayish-brown chert $(n=1)$, and a light gray chert $(n=1)$. The two cortical pieces have a smoothed exterior surface, suggesting they come from local river gravels.

The 27 ceramic sherds from the shovel testing at the Larry Byrd Pine Plantation site are from vessels tempered with grog ( $\mathrm{n}=19,70$ percent) or bone ( $\mathrm{n}=8,30$ percent); this includes 26 body sherds and one base sherd. The sherd sample size and the absence of decorated sherds in the assemblage suggests that the site may have been occupied during some part of the Woodland period (ca. 2500-1150 years B.P.) by ancestral Caddo peoples belonging to the Mill Creek culture (see Ellis 2013; Shafer and Walters 2010).

In addition to the artifacts recovered in the shovel testing, a single plain grog-tempered body sherd was collected from the surface of the site. This sherd also has a distinctive sandy paste. 


\section{Road-cut Site (41SM309)}

The Road-cut site has ancestral Caddo archaeological deposits that cover an estimated $2400 \mathrm{~m}^{2}$ area of an upland landform (see Figure 2) in the Sabine River valley. The deposits are in fairly deep brown sandy loam sediments ranging from $60 \mathrm{~cm}$ bs to at least $103 \mathrm{~cm}$ bs. Three shovel tests have been excavated at the site, and two (ST 1 and ST 3) have artifacts; a surface collection was also taken from the site.

In the shovel tests, two grog-tempered body sherds from utility ware vessels were recovered between $0-40 \mathrm{~cm}$ bs. One has rows of fingernail punctations and the other has horizontal and diagonal opposed incised lines, likely from a Dunkin Incised jar (Figure 3a; see Suhm and Jelks 1962:Plate 19g).

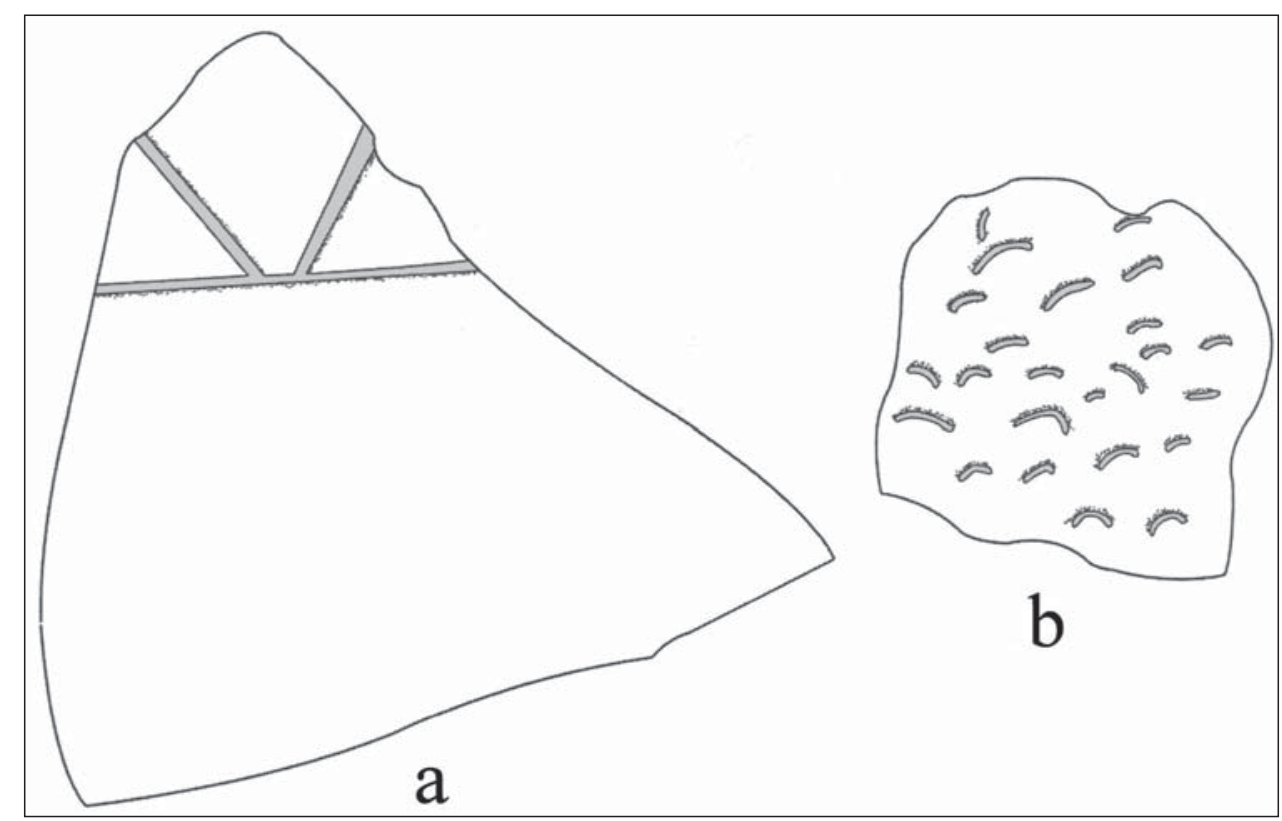

Figure 3. Decorative elements on utility ware sheds from the Road-cut site (41SM309): a, Dunkin Incised body sherd; b, fingernail punctated body sherd.

The surface collection has six grog-tempered body sherds. Three are plain, one has parallel incised lines, another has a row of tool punctations, and the last sherd has rows of fingernail punctations (see Figure $3 \mathrm{~b}$ ). This may be from a Kiam Incised vessel (see Suhm and Jelks 1962:Plate 45c, e). The few decorated sherds from the site suggest that the Road-cut site was occupied by ancestral Caddo peoples at the same time as the occupation at the nearby Boxed Spring mound center.

Also in the surface collection from the Road-cut site is a ferruginous sandstone mano. It has one smoothed grinding surface that is $63 \times 54 \mathrm{~mm}$ in length and width.

\section{Melton Site (41SM310)}

Not much is known about the Melton site as only surface collections were done here. The prehistoric artifacts found at the site include a non-cortical piece of local quartzite lithic debris and a ferruginous sandstone mano and bi-pitted stone. The pits are both $18 \mathrm{~mm}$ in diameter.

A few historic artifacts were also collected from the site, namely one plain whiteware body sherd and three bottle glass sherds of brown, aqua, and amethyst. The latter sherd is from a bottle manufactured between ca. 1890-1918. There may have been a homestead or a tenant farm on this upland ridge. 


\section{SUMMARY AND CONCLUSIONS}

Archaeological investigations, primarily shovel testing, in the Winter of 2003 in the Sabine River valley in northeastern Smith County in East Texas led to the identification of four small prehistoric sites (41SM307310). Three of the sites have sherds from grog and/or bone-tempered vessels, while the fourth site has a few prehistoric lithic artifacts and a small sample of early 20th century artifacts. The sites with sherds from ceramic vessels were likely each occupied by ancestral Caddo peoples, one perhaps during some part of the Woodland period (Larry Byrd Pine Plantation site, 41SM308) and another during the Early Caddo period (Road-cut site, 41SM309). This latter site was likely part of the ca. A.D. 1000-1200 Caddo community in this part of the Sabine River valley centered at the nearby Boxed Spring (41UR30) mound center.

\section{ACKNOWLEDGMENTS}

Lance Trask prepared the figures in this article.

\section{REFERENCES CITED}

Ellis, L. W.

2013 Woodland Ceramics in East Texas and a Case Study of Mill Creek Culture Ceramics. Bulletin of the Texas Archeological Society 84:137-180.

Perttula, T. K.

2011 (assembler) Archaeological and Archaeogeophysical Investigations at an Early Caddo Mound Center in the Sabine River Basin of East Texas, Special Publication No. 15. Friends of Northeast Texas Archaeology, Austin and Pittsburg.

Shafer, H. J. and M. Walters

2010 The Browning Site (41SM195A) Lithics: Considering Patterns of Identity and Interaction through Lithic Analysis. Bulletin of the Texas Archeological Society 81:127-151.

Suhm, D. A. and E. B. Jelks (editors)

1962 Handbook of Texas Archeology: Type Descriptions. Special Publication No. 1, Texas Archeological Society, and Bulletin No. 4, Texas Memorial Museum, Austin. Reprinted in 2009, Gustav's Library, Davenport, Iowa. 